\title{
Strengthening Strategy of Indonesian Local Legislative Councils on Budget Oversight
}

\author{
Mintarti Indartini \\ Management Department, University Of Merdeka Madiun, Indonesia \\ Assistriadi Widjiseno* \\ Informatics Engineering Department, University Of Kahuripan Kediri, Indonesia \\ Nurharibnu Wibisono \\ Accounting Department, University Of Merdeka Madiun, Indonesia
}

\begin{abstract}
Purpose -The purpose of this paper is to investigate the strengthening approach followed by Indonesian local legislative councils in particular on local government annual budget oversight, this study aims to discuss and examine what and how the approach of strengthening must be managed and conducted by local legislative members.

Design/methodology/approach - The study is based on the results of a qualitative in depth interviews involving 5 members of local legislative councils, 1 professional regional planning and budgeting consultant, 1 professional facilitator in strengthening local legislative councils and local council secretariat which is in charge of organizing secretarial and financial administration, supporting the implementation of the tasks and functions of the local legislative councils. The in depth interviews uses the case study method in five districts in east java province, Indonesia.

Findings - The findings confirm that strengthening budget oversight by local legislative councils must begin from planning, budgeting process to the oversight of public services. In order budget oversight to be more directed and planned, the local legislative councils must implement several steps including determining targets and standards, measuring actual performance, comparing results with predetermined targets and standards, taking necessary corrective actions. Another thing that is quite crucial for local legislative councils is encouraging the realization of an effective and efficient organization. To realize such an organization, every government agency must be prepared to utilize the wealth of knowledge it has. Knowledge management is an effort to improve organizational capabilities in managing intellectual assets: existing knowledge and experience. Lack of capacity was not just individual, therefore it is very necessary a comprehensive capacity-development package is needed for member of local legislative councils. And the supporting from local council secretariat is very important and crucial in budget oversight activities

Practical implications - The findings have implications for local legislative council should be develop standard operating procedures in budget oversight as a standardization of the mechanism must be conducted by local legislative members in completing their budget oversight, reducing the level of errors and omissions that may be carried out in implementing their duties and increasing the efficiency and effectiveness of the implementation of duties and responsibilities of individuals and the organization as a whole;
\end{abstract}

Keywords : Budget Oversight, Local Legislative Councils, Strengthening Strategy, Knowledge Management, Indonesia

Paper type : Research paper

DOI: $10.7176 / \mathrm{EJBM} / 11-24-07$

Publication date: August $31^{\text {st }} 2019$

\section{Introduction}

In the past decade much research has focus on local government budget and local parliamentarians become key issue in democratic governance. And nowadays there are still many issues, topics and research gaps that have not yet confirmed the results and findings the conclusions. When reviewing of previous research we found that some researchers have discussed about capacity building of parliamentarians, overspending political budget, the role of local political elites, analysis of public service expense policy, the role and impact between councilor education levels, increasing the effectiveness and efficiency of public service expenditure budget allocations, participatory budgeting, transparency of local government, budget fraud and the impact of corruption.

As community representatives, the main task of local legislative councils is to making decisions on behalf of the community and citizens, so, what is the role of local legislative councils expected by the community is

* As policymakers, they can contribute to policy-making process through their role in supervision function, through advisory groups, committees and in their interactions with the executive.

* As a supervisor, local legislative councils is required to oversee the government. This is an 
extension of the representative role and as a key function in accountable democracy. And conceptually, supervision function is based on check and balance domain of government and parliamentary functions

* As initiator, local legislative councils being able to initiate or approve regional regulations. Ratification of regulations involves interests balance between executive and legislature, as well as negotiating results that benefit the community.

* As a decision maker, member of local legislative councils are the main drivers of local policy and need to make good decisions for community, and help make decisions that affect not only to citizens but also affects all member of local legislative councils and institutions.

* As agent of change, member of local legislative councils should be an example for others in promoting positive social change. A change agent works in a network, makes connections and works together to create public values and develop a common good.

local legislative councils is a legislative body that has budget rights (the right to set a budget while monitoring the implementation of the local budget), and in implementing the people's mandate, the local council should be able to produce political decisions / public policies that have a positive impact through the instruments of local legislative councils functions, namely the functions of legislation, budgeting and supervision. All implementation of these functions is at the core of representative politics. In order for the supervision function to run efficiently and effectively it is necessary organizing processes that are good and directed. Step by step supervision is set out in the work plan accompanied by scheduling and involvement of various parties from inside and outside the local legislative councils. The final product of the supervision process is a recommendation that must be addressed by the executive. but it's remains unclear what and how the approach or strategy of strengthening must be managed and conducted by local legislative members, especially on budget oversight.

The purpose of this study was to investigate the strengthening strategy followed by Indonesian local legislative councils in particular on local budget oversight, this study aims to discuss and examine what and how to ensure that local budget allocations are in line with local development priorities and are aimed at improving the welfare of the community and its use and utilization economically, efficiently and effectively and managed transparently and accountably to minimize the occurrence of budget leakage or corruption.

\section{Literature Review}

Local budgets must be directed at creating employment / reducing unemployment and waste of resources, as well as increasing the efficiency and effectiveness of the economy. (GOI(Government Of Indonesia), The Government Regulation No. 58/2005). Local budget policies must be managed effectively, efficiently, economically, transparently, responsibly by taking into account the principles of fairness, propriety and benefits for the community (GOI (Government Of Indonesia), Ministry Of Home Affairs Regulation No. 13/2006).

The strategic plan for parliamentary development has an important and critical role and provides a strong and reliable framework. By way of harmonizing the vision, mission and common goals and involving stakeholder participation. This can prevent failure in the parliament's capacity building program due to the gap between the reality of needs and expectations. whereas in fragile environments greater and wider efforts are needed in developing parliamentary capacity. (Severine M. Rugumamu,2011). Direct local elections in Indonesia is a trigger of political budget cycles (PBCs) in government administrative spending are significantly stronger if the incumbent runs for reelection. And the opposite of indirect local elections in Indonesia, political budget cycles (PBCs) is not occur. (Bambang Suharnoko Sjahrir,2013). The political competition in indonesian districts has a significant influence on administrative expenditures overspending in local governments budget, and and become misallocation of public resources. And amounting to almost a third of the total local budget. But the other findings are increased administrative spending is not led by the proliferation of districts. (Bambang Suharnoko Sjahrir,2014). Local political business elites who have an interest in maintaining and developing their power and wealth. often affecting public policy decision-making processes, both economically and politically. including controlling the utilization of public space. lobbying and negotiations among the local political business elites had a big influence (Rika Kurniaty, 2014).

The direction of local government annual budget policy is the key role to implement good governance and fulfillment of public services. Local budget policy must be guarantee consistency between the local planning process and local budgeting and reflect the accomplishment of vision, mission, target and goal of local mediumterm development plan (Hendri Koeswara, 2014). The implementation of regional government is directed at accelerating the realization of community welfare through improving services, empowerment, and community participation, as well as enhancing regional competitiveness by taking into account the principles of democracy, equity, justice and distinctiveness of a region within the Unitary State of the Republic of Indonesia (GOI(Government Of Indonesia), The law No. 23/2014). Capacity-building program for the Lithuanian parliamentarians to fulfil their functions efficiently and effectively is not systematic, it remains not completely 
clear about competency and qualification standards in order to successfully fulfil them for the benefits of the nation. and this problem becomes a such activities are waste of tax payers' money. So capacity-building program for the Lithuanian parliamentarians should be improved (Saulius Nefas, 2015).

There is a strong correlation between councilor education levels and efficiency of municipal legislative chambers. The findings indicates that the more higher level of education of legislative members will be exhibit better and superior legislative performance. In order to reach a good legislative performance it is necessary completed higher education is 15 years or 17 years. (Alexandre Manoel Angelo Da Silvaa, 2015). There are three recommendations to improve the efficiency and allocation of public spending which consists of reforming budget formulation and execution by implementing performance-based budgeting or also called output-based approach and continue the fight against corruption or eradicate corruption. Making decentralisation work better by improve transferring authority to local governments or coordination between central and local governments but also to bring local councils and citizens into planning, budgeting, and service delivery processes. Improving the allocation and efficiency of expenditures by focus on improving quality of health and education sectors (Ollivaud, P, 2017).

The generation of own-source taxes is not influenced by the direct election of local government executives, but on local governments with directly elected heads spend less, especially on infrastructure sector. And on education, health, and infrastructure sectors, efficiency effects are found to be robust. Local governments with directly elected heads also spend more efficiently in pursuit of service outcomes than local governments with indirectly elected officials. (Blane D. Lewis, 2017). Participatory regional budgeting processes do not always involve the poor, lack of participation from the poor is not unique anymore and often occurs. From the results of the study it was found that spending on the infrastructure sector did not target the poor, in fact many households in the poor received fewer of these infrastructure projects. This is biased rather than a participatory regional budgeting process that should be designed to prioritize poor households. Therefore more research is needed to identify errors, vulnerability points at the process and decision-making stages and to diagnose potential problems that will be made improvements for policy makers. (Tara Grillos,2017). The budgeting process influenced by a combination of political logic and managerial logic. intervention from political leaders is becomes a part of decision making in budgeting process especially in the process of revenue budget setting, including determining the amount of revenue that will be collected, allocating resources to expenditures and setting up standar pricing or to determine local tax rate. And political leader use the budgeting process as a tool to fulfill political commitment to the constituents. (Ade Palupi, 2017).

A fundamental problem when conducting an analysis to determine dimension of local budget proportion allocations prioritized for public services improvement and economic fulfillment, people'ssocial, and cultural rights in the city's/regency's APBD document is amount of data and information to be processed,budget complexity,data structure as well as presentation format of information allocation andlimited budget distribution. (Assistriadi Widjiseno, 2018). To ensure transparency and accountability of discussion and legitimation of local government district annual budget must be involved executive (District Head, Municipality Head/Mayor, local government secretariat), legislative (Local Legislative Councils), independent regional planning and budgeting consultant and Civil society organization (Assistriadi Widjiseno, 2018). The transparency of local government in Indonesia influenced by a combination of political environment and the quality of financial reporting through the audit opinion and have a significant positive effect. But on the other hand the transparency of local government in Indonesia is not depend on local government response to the regulation or size of the local government. The agency, legitimacy and institutional theory have an important role in the underlying local government transparency practices in Indonesia. (I Made Pradana Adiputra, 2018).

Political parties that control parliament and control more than half of the seats in parliament are the cause of the emergence of local government budget allocation policies in the health sector and improvements to public health services. However, this only happens at the beginning of the government for one or two years. And after that this positive effect will disappear. And towards the end of the administration period, the majority of political coalitions will change the direction of their attention and policies to support massive infrastructure development. Which is where the infrastructure development process is allegedly going to get a lot of loan funds from implementing partners that will be used to finance the election process in the coming year. so that at that time there will be a budget lie and budget corruption (Blane D. Lewis, 2019). Various problems faced by the Indonesian local legislative council in the local budgeting are weak data support and access to data sources that can help in making general policy of local government annual budget and program supervision. The data that become basis policy is more based on data sourced from the executive. And the low understanding of some members (tend to be the majority) towards various rules and budgeting grouping (nomenclature) in local government annual budget causes local legislative council members not to be detailed in conducting discussions. So based on this various problems it is necessary to development of knowledge management strategy to strengthening local legislative councils on budget oversight. (Assistriadi Widjiseno, 2019) 


\section{Discussions And Findings}

The main objective of the study underlying this paper was to examine what and how the strengthening strategy must be managed and conducted also provides information and guide for members of local legislative in conducting one of its roles : legislative budget oversight. The objective of legislative budget oversight is to ensure that all public policies related to budget cycle are carried out in accordance to the legal requirement and focus on public priorities.

According to the GOI(Government Of Indonesia), The law No. 23/2014), states that local legislative councils has the duty and authority to carry out supervision of the implementation of the local regulation and local budget. This is a mandate and legal umbrella for the local legislative councils to carry out its oversight function. However, the local planning and budgeting process is still faced with several weaknesses including: community aspiration nets has not been effective, mark up of budget value. lack of supporting data, lack of capacity of that local legislative councils members and local governments in developing affairs priorities and program, the existence of individual, and group interests that cause program priorities do not accommodate people's needs, the program priority is not in accordance with peopleneeds as a result of lack of supporting data, lack of capacity of local government, people cannot/less able to give input or correct if rapbd does not fit their needs, people cannot participate in overseeing the implementation of local budget and the local budget is late to be approved, therefore a strategy for strengthening the local legislative councils is required in the supervision of the budget covering all local budget cycles, namely since planning, implementing, approving, revising, reporting and accountability reports.

There is a need a good organize and directed process so that the supervision function can run efficiently and effectively. Step by step supervision is set out in the work plan accompanied by scheduling and involvement of various parties or steakholders from inside and outside the local legislative councils. And the final product of the supervision process is a recommendation that must be addressed by the executive. And the local legislative councils must provide clear, specific and detailed directions on how the corrective actions should be taken by the responsible local government sector department. And there are a found distortion of local budget, the recommendations given by the local legislative councils are in the form of an act of termination or cancellation, in addition to legal follow-up. If such follow-up is needed, then the local legislative councils must be able to provide clear direction and input to all agencies responsible for legal and judicial processes.

One of example local budget distortion is that mark-up generally occurs on the expenditure side while markdown is done on the income side. mark-up on the budget side can occur in various aspects, for example : costs, volume, quality, materials and so on. The budget plan is made in an excessive and unrealistic manner, far above the actual needs.

In the budgeting process there are several critical points that need to get extra attention from members of local legislative councils, including the consistency of the process of determining programs and activities in the RPJMD document (local medium-term development plan), local government annual development plan, KUA and PPAS (general budget document \& budget policy priorities and ceiling document) and APBD (local government annual budget). Another thing that needs to be monitored is towards the targets and performance benchmarks and determining the standard unit price and volume of goods and services for each activity.

Local planning and budgeting processes that are routinely carried out every year, it will continue to produce data and information with 3 characteristics, namely volume (data capacity), variety (data diversity) and velocity (data production speed) are large. Whereas until now various problems faced by the local legislative councils in the budget oversight are weak data support and access to data sources that can help local legislative councils in making general policy of KUA and PPAS (general budget document and budget policy priorities and ceiling document) and APBD (local government annual budget) and program supervision. The data that become basis policy is more based on data sourced from the executive. the low understanding of some members (tend to be the majority) towards various rules and budgeting grouping (nomenclature) in APBD (local government annual budget) causes local legislative council members not to be detailed in conducting discussions. The draft submitted almost at the end of time happens often, even late, submission of RAPBD (draft local government annual budget) from Executive to local legislative councils causes a narrow time of observation (both in Commission and in the Budget Committee), thus causing APBD (local government annual budget) determination withdrawal. So based on these problems it becomes a necessity for the local legislative councils to develop knowledge management strategies. Knowledge management is a structured and systematic effort to develop and use the knowledge that is owned to help the decision-making process for improving organizational performance. Activities in knowledge management include efforts to obtain, store, process and retrieve, use and disseminate, and evaluate and perfect knowledge as an intellectual asset of the organization. (GOI (Government Of Indonesia), Ministry For State Administrative And Bureaucratic Reform Regulation No. 14/2011) 


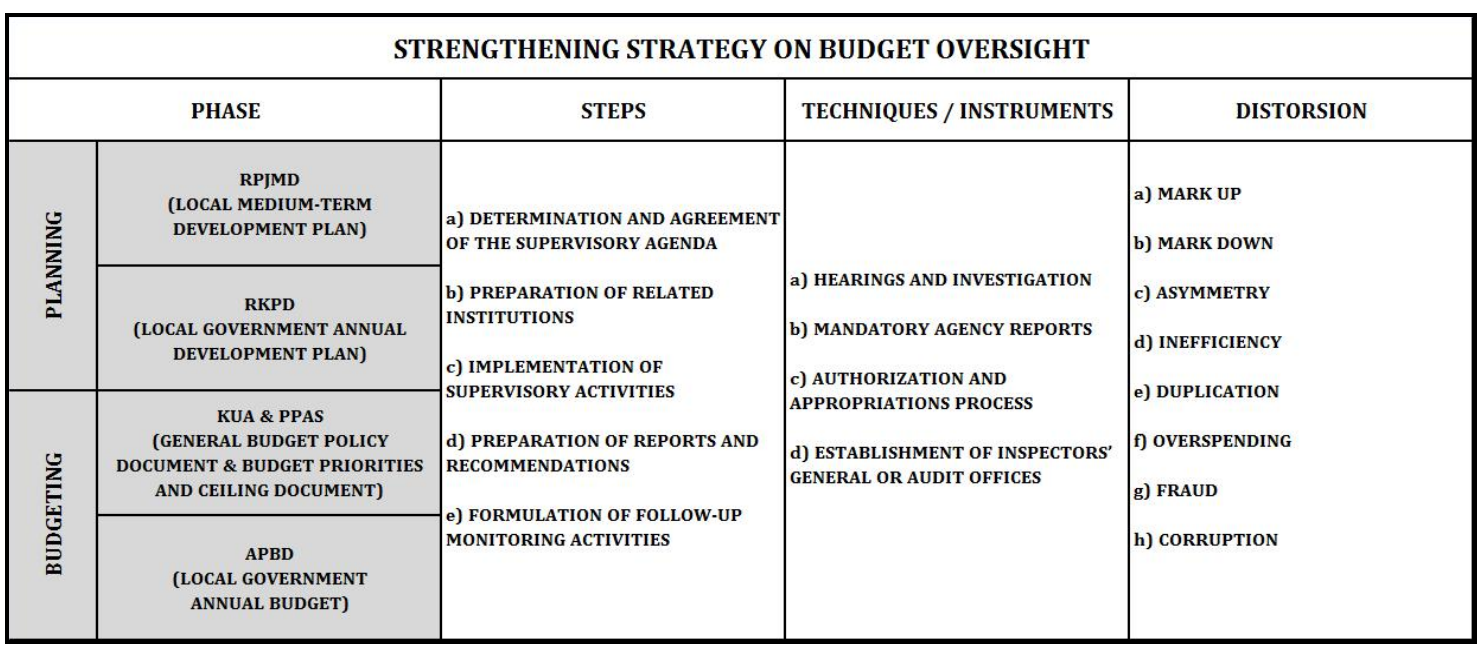

\begin{tabular}{|c|c|c|c|c|}
\hline \multicolumn{5}{|c|}{ STRENGTHENING STRATEGY ON BUDGET OVERSIGHT } \\
\hline & PHASE & RECOMMENDATION & PARTNERSHIP & TOOLS \\
\hline \multirow{2}{*}{$\sum_{\substack{\mid \\
a}}^{u}$} & $\begin{array}{c}\text { RPJMD } \\
\text { (LOCAL MEDIUM-TERM } \\
\text { DEVELOPMENT PLAN) }\end{array}$ & \multirow{4}{*}{$\begin{array}{l}\text { a) CORRECTIVE ACTION } \\
\text { b) TERMINATION OR CANCELLATION } \\
\text { ACTION } \\
\text { c) LEGAL FOLLOW-UP }\end{array}$} & \multirow{4}{*}{$\begin{array}{l}\text { a) CIVIL SOCIETY ORGANIZATION } \\
\text { b) INTEREST GROUPS } \\
\text { c) POLITICAL ACTIVISM } \\
\text { d) RESEARCH INSTITUTIONS } \\
\text { e) MEDIA }\end{array}$} & \multirow{4}{*}{$\begin{array}{l}\text { a) ANALYTICAL INFORMATION } \\
\text { SYSTEM } \\
\text { b) DECISION SUPPORT SYSTEM } \\
\text { c) EXPERT SYSTEM } \\
\text { d) LESSONS LEARNED MANAGEMENT } \\
\text { SYSTEM } \\
\text { e) KNOWLEDGE MANAGEMENT } \\
\text { SYSTEM }\end{array}$} \\
\hline & $\begin{array}{c}\text { RKPD } \\
\text { (LOCAL GOVERNMENT ANNUAL } \\
\text { DEVELOPMENT PLAN) }\end{array}$ & & & \\
\hline \multirow{2}{*}{ 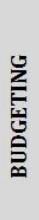 } & $\begin{array}{c}\text { KUA \& PPAS } \\
\text { (GENERAL BUDGET POLICY } \\
\text { DOCUMENT \& BUDGET PRIORITIES } \\
\text { AND CEILING DOCUMENT) }\end{array}$ & & & \\
\hline & $\begin{array}{c}\text { APBD } \\
\text { (LOCAL GOVERNMENT } \\
\text { ANNUAL BUDGET) }\end{array}$ & & & \\
\hline
\end{tabular}

Figure 1. Strengthening Strategy On Budget Oversight

And one of the basic competencies that must be built when making the central theme of local budget oversight is budget literacy capacity, budget analysis, budget politics and regional budget policy advocacy. However, to realize this competency is constrained by several technical aspects including, the large amount of data and information that must be processed, the complexity of the budget data structure and the format of the presentation of limited allocation and budget distribution information. Therefore information technology support is needed as a solution, where information technology has been proven to have capability and reliability in processing and utilizing data that is available in large, fast, and diverse volumes. information technology (information technology approach) is a top priority that must be realized.

\section{Conclusions}

Strengthening budget oversight by local legislative councils must begin from planning, budgeting process to the oversight of public services. This is because supervision means the process of measuring performance and taking action to ensure that results (output and outcomes) are in accordance with what is desired and guarantee that everything is going according to the standards set (on the right track).

In order budget oversight to be more directed and planned, the local legislative councils must implement several steps including determining targets and standards, measuring actual performance, comparing results with predetermined targets and standards, taking necessary corrective actions. While the form of oversight of the local legislative councils can be in the form of responding to complaints from the public who are direct beneficiaries of public services. Therefore it is very necessary transparency and citizen engagement in the council budget process

The low level of understanding of some members (the tendency of the majority) towards various rules and the grouping (nomenclature) of the local budget has made local legislative councils not detailed in conducting budget discussions and supervision. Lack of capacity was not just individual, therefore it is very necessary a comprehensive capacity-development package is needed for member of local legislative councils.

Various problems faced by the local legislative councils in the budget oversight is weak data support and 
access to data sources that can help local legislative councils in making General Policy of local budget and usually the data that become basis policy is more based on data sourced from the executive. While one of the basic competencies that must be built when discussing and supervising local budget is budget literacy capacity, budget analysis, budget politics and supervision and advocacy of local budget policies. However, to realize this competency is constrained by several technical aspects including, the large amount of data and information that must be processed, the complexity of the budget data structure and the format of the presentation of limited allocation and budget distribution information. Therefore, information technology support is needed as a solution, where information technology has been proven to have capability and reliability in processing and utilizing data available in large, fast, and varied volumes.

The supporting from local council secretariat is very important and crucial in budget oversight activities, local council secretariat which is in charge of organizing secretarial and financial administration, supporting the implementation of the tasks and functions of the local legislative councils, manages all its correspondence, public meetings and travel, and providing and coordinating technical assistance that needed by the local legislative councils in implementing their rights and functions according to their needs including the delivery is to support the availability of documents or information such as RPJMD document (local medium-term development plan), local government annual development plan, KUA and PPAS (general budget document \& budget policy priorities and ceiling document) and APBD (local government annual budget).

\section{Recommendation}

local legislative council should be develop standard operating procedures in budget oversight which is a series of written instructions standardized on various processes for implementing organizational activities, how and when to be carried out, where and by whom is done. which consists of administrative standard operational procedures, namely standard procedures that are general in nature and not detailed from activities carried out by more than one implementing person with more than one role or position and technical standard operational procedures, namely very detailed standard procedures of activities carried out by one implementing person with one role or position

\section{Acknowledgments}

The authors would like to thank the Directorate of Research and Community Service, the Directorate General of Strengthening Research and Development of the Republic of Indonesia Ministry of Research, Technology and Higher Education which has provided financial support to this research.

\section{REFERENCES}

GOI (Government Of Indonesia) (2005). Peraturan Pemerintah [The Government Regulation Of] : Pengelolaan Keuangan Daerah [Regional Financial Management]. No. 58/2005. Jakarta, Indonesia: Author.

GOI (Government Of Indonesia) (2006). Peraturan Menteri Dalam Negeri [Ministry Of Home Affairs Regulation] : Pedoman Pengelolaan Keuangan Daerah [Regional Financial Management Guidelines]. No. 13/2006. Jakarta, Indonesia: Author.

GOI (Government Of Indonesia) (2011). Peraturan Menteri Negara Pendayagunaan Aparatur Negara Dan Reformasi Birokrasi [Ministry For State Administrative And Bureaucratic Reform Regulation] : Pedoman Pelaksanaan Program Manajemen Pengetahuan [Guidelines For Implementing The Knowledge Management Program ]. No. 14/2011. Jakarta, Indonesia: Author.

Severine M. Rugumamu, (2011), "Capacity Development In Fragile Environments: Insights From Parliaments In Africa", World Journal of Entrepreneurship, Management and Sustainable Development, Vol. 7 Issue: 2/3/4, pp.113-175

Bambang Suharnoko Sjahrir, (2013), “Political Budget Cycles In Indonesia At The District Level”, Economics Letters, 120, pp. 342-345

GOI (Government Of Indonesia) (2014). Undang-Undang [The law of]: Pemerintahan Daerah [Local Government]. No. 23/2014. Jakarta, Indonesia: Author.

Bambang Suharnoko Sjahrir, (2014), “Administrative Overspending in Indonesian Districts :The Role of Local Politics”, World Development,Vol. 59, pp. 166-183

Rika Kurniaty, (2014), "Local Elites And Public Space Sustainability : The Local Elite Roles In The Presence And Usage Of Public Space In Malang Raya, Indonesia”, Procedia Environmental Sciences, 20, Pp. 506 515

Hendri Koeswara, (2014), "The Analysis Of Public Service Expense Policy In The Regional Budget", International Journal Of Administrative Science \& Organization, Vol 21, Number 1

Saulius Nefas, ( 2015 ), "Capacity Building Of Parliamentarians : Problems And Perspectives In Lithuania", Procedia - Social and Behavioral Sciences, 191, pp. $402-406$

Alexandre Manoel Angelo Da Silvaa, (2015), "Efficiency Of Municipal Legislative Chambers", EconomiA, 16, 
pp. $60-75$

Ollivaud, P. (2017), “Improving The Allocation And Efficiency Of Public Spending In Indonesia”, OECD Economics Department Working Papers, No. 1381, OECD Publishing, Paris.

Blane D. Lewis, (2018), "Local Government Form In Indonesia: Tax, Expenditure, And Efficiency Effects", St Comp Int Dev, 53, pp. 25-46

Tara Grillos, (2017), "Participatory Budgeting And The Poor : Tracing Bias In A Multi-Staged Process In Solo Indonesia, World Development, Vol. 96, pp. 343-358

Ade Palupi, (2017), "The Institutional Logics Of Local Government Budget In Indonesia", SHS Web Of Conferences 3408002

Assistriadi Widjiseno, (2018), "Design And Development Of APBD (Indonesian Local Government District Annual Budget) Information Systems Analysis Application”, International Journal Of Advanced Research In Computer Science, Volume 9, No. 4, ISSN No. 0976-5697

Assistriadi Widjiseno, (2018), "Pemodelan Proses Bisnis Sistem Informasi Analisis APBD Dengan Business Process Modelling Notation (BPMN)", Jurnal Sistem Informasi Indonesia (JSII), Vol 3 No 2, pp. 1-14

I Made Pradana Adiputra, (2018) "Transparency Of Local Government In Indonesia", Asian Journal Of Accounting Research

Assistriadi Widjiseno, (2019), "Systematic Literature Review Of Knowledge Management Strategy For Optimization Budgeting Function On Indonesian Local Legislative Council”, Information and Knowledge Management, Vol.9, No.4,ISSN 2224-5758 (Paper) ISSN 2224-896X (Online) DOI : 10.7176/IKM

Blane D. Lewis, (2019), "The Impact Of Majority Coalitions On Local Government Spending, Service Delivery, And Corruption In Indonesia”, European Journal Of Political Economy, 58, Pp. 178-191 